\title{
MICROSTRUCTURE AND MECHANICAL PROPERTIES OF GRAPHENE-REINFORCED ALUMINUM-MATRIX COMPOSITES
}

\author{
MIKROSTRUKTURA IN MEHANSKE LASTNOSTI Z GRAFENOM \\ OJAČANIH KOMPOZITOV Z ALUMINIJEVO MATRICO
}

\author{
Xiaoming Du, Kaifeng Zheng, Fengguo Liu \\ Shenyang Ligong University, School of Materials Science and Engineering, Nanping Middle-Road 6, Hunnan Street, Shenyang 110159, China \\ du511@163.com \\ Prejem rokopisa - received: 2018-02-13; sprejem za objavo - accepted for publication: 2018-06-28
}

doi: $10.17222 /$ mit.2018.021

\begin{abstract}
Graphene has a high fracture strength, good ductility and low coefficient of thermal expansion, making it an ideal reinforcement for composite materials. This paper reports on an aluminum-matrix composite reinforced with graphene (graphene/Al) using ball milling and hot-press sintering. The effect of the graphene content on the microstructures, mechanical properties and fracture mechanisms of the composites were investigated. It is shown that $0.25 \mathrm{w} / \%$ and $0.5 \mathrm{w} / \%$ graphene contents modified with copper are homogeneously dispersed into the aluminum matrix. The composite with the $0.5 \mathrm{w} / \%$ graphene content exhibits the highest tensile strength and elongation; its improvement over the unreinforced aluminum matrix is $31.0 \%$ and $30.6 \%$, respectively. With the increasing graphene content up to $1.0 \mathrm{w} / \%$, the aggregation of graphene in the composite is apparent, seriously reducing the tensile properties. The fracture mechanism of the composites changes from ductile to brittle.

Keywords: aluminum-matrix composites, graphene, microstructure, mechanical properties
\end{abstract}

Grafen ima visoko lomno trdnost, dobro duktilnost in nizek koeficient termičnega raztezka, zato je idealen za ojačitev kompozitnih materialov. V članku avtorji poročajo o kompozitu na osnovi aluminija, ojačanem z grafenom (grafen/Al), izdelanem s krogličnim mletjem in sintranjem pod tlakom. Raziskovali so vpliv dodatka grafena na mikrostrukturo, mehanske lastnosti in mehanizem loma izdelanih kompozitov. V prispevku so pokazali, da je dodatek $0,25 w / \%$ in $0,5 w / \%$ grafena, modificiranega $z$ bakrom, homogeno porazdeljen v matrici Al kompozita. Kompozit z 0,5 w/\% grafena ima najvišjo natezno trdnost in raztezek, kar je $31,0 \%$ oz. 30,6 \% bolje v primerjavi z neojačanim kompozitom. Z naraščajočo vsebnostjo vsebnosti grafena do 1,0 w/\% se pojavlja kopičenje grafena v matrici kompozita, kar močno zmanjša njegove natezne lastnosti. Mehanizem loma kompozita se tako spreminja iz duktilnega $\mathrm{v}$ krhkega.

Ključne besede: kompoziti na osnovi aluminija, grafen, mikrostruktura, mehanske lastnosti

\section{INTRODUCTION}

Aluminium-matrix composites have a high strengthto-weight ratio, high modulus-to-weight ratio, good damage tolerance, good wear resistance, excellent thermal conductivity and corrosion resistance, which make them highly competitive against the conventional aluminium alloys or even titanium alloys and steels for many structural applications, such as the construction, aerospace, transportation, automotive and military industries. ${ }^{1-3}$ At present, particulate (such as graphite, $\mathrm{Si}_{3} \mathrm{~N}_{4}$, $\mathrm{SiC}, \mathrm{TiN}, \mathrm{BN}, \mathrm{MgO}$ and $\mathrm{Al}_{2} \mathrm{O}_{3}$, etc. ) reinforced aluminum-matrix composites are widely studied because of their advantages such as low cost, isotropic properties and the possibility of secondary processing, facilitating the fabrication of secondary components. ${ }^{4-7}$

The main research trend of aluminum-matrix composites is to continue to improve their comprehensive properties (such as tensile and fracture strength, thermal conductivity, friction and wear properties); meanwhile, they have good ductility and fatigue resistance. In order to get high-ductility, high-strength aluminum-matrix composites, high-performance reinforcement materials are necessary. Among them, carbon materials are out- standing, such as graphite whiskers, carbon fibers, carbon nanotubes (CNTs) and graphene (GNP).

In recent years, carbonaceous nanomaterials including graphene and carbon nanotubes (CNTs) have emerged as an important class of new materials for structural engineering and functional device applications due to their extraordinary high elastic modulus and mechanical strength as well as excellent electrical and thermal conductivities. In addition, most studies show that graphene is considered a most effective reinforcing filler for fabricating composite materials. ${ }^{8-11}$ It is because graphene has some exceptional properties: excellent electric properties, ${ }^{12}$ high thermal conductivity, ${ }^{13}$ high Young's modulus ${ }^{14}$ and high tensile stress. ${ }^{15}$ Additionally, graphene is extremely light. The density of graphene was estimated to be as low as $1.06 \mathrm{~g} \cdot \mathrm{cm} .{ }^{3,16}$ These exceptional properties make it a perfect reinforcement for metal-matrix composites. A lot of research work has been carried out for the fabrication of aluminium composites reinforced with graphene nanosheets, ${ }^{17-19}$ graphene nanoflakes, ${ }^{18-21}$ few-layered graphene, ${ }^{22}$ or its derivatives such as graphene oxide and reduced graphene oxide. ${ }^{23,24}$ Cold compaction followed by hot isostatic pressing,,$^{18}$ as well as hot extrusion, ${ }^{17,24,20,21}$ vacuum hot press and/or 
hot rolling 22 are commonly used, according to the literature, to manufacture solid pure aluminium and graphene-reinforced aluminium-matrix composite specimens.

Wang et al. reported that the tensile strength of $\mathrm{Al}$ composites reinforced with only $0.3 \mathrm{w} / \%$ graphene nanosheets using powder metallurgy was $249 \mathrm{MPa}^{24}$ It was a $62-\%$ enhancement over the unreinforced $\mathrm{Al}$ matrix. Li et al. reported that an $\mathrm{Al}$ composite reinforced with only 0.3 w/\% graphene oxide showed an $18-\%$ and $17-\%$ increase in the elastic modulus and hardness, respectively, over the unreinforced $\mathrm{Al}^{23}$ Yan Shao-jiu et al. reported that the tested tensile strength and yield strength of $0.3 w / \%$ graphene-reinforced Al-matrix composites fabricated with powder metallurgy, showed an increase of $25 \%$ and $58 \%$, respectively, compared to the pristine Al alloy. ${ }^{18}$ The ductility of the composite was almost as good as or even a little better than the pristine alloy. Although the above studies showed that the mechanical properties of aluminum alloys can be improved by adding graphene, it is still a great challenge to produce aluminum-matrix composites reinforced by well-dispersed graphene via a conventional metallurgical process due to a high-temperature environment and a huge density difference between graphene and aluminum matrix. Great difficulties are encountered during the synthesis and unknown interfacial chemical reactions between graphene and metal matrices.

In this work, Al composites reinforced with graphene were fabricated by ball milling and hot-press sintering. The distribution and morphology of graphene in the Al matrix were analyzed. The mechanical properties of $\mathrm{Al}$ composites reinforced with graphene were tested and the relevant strengthening mechanisms of graphene were discussed based on the primary experimental evidences.

\section{EXPERIMENTAL PART}

\subsection{Materials}

The graphene sheets used in our experiments were prepared with modified Hummers method as reported previously. ${ }^{25}$ The experimental material was natural graphite with a particle size of about 45 um. Natural graphite was reduced at $95{ }^{\circ} \mathrm{C}$ for $24 \mathrm{~h}$ using hydrazine hydrate. The preparation method was similar to that from Reference ${ }^{25}$.

To improve the interface wetting between graphene and aluminum matrix, graphene was coated with copper using the chemical plating method. Graphene was added into a plating solution including $10 \mathrm{~mL} / \mathrm{L} \mathrm{CuSO}_{4}$, $1 \mathrm{~mL} / \mathrm{L} \mathrm{NiSO}_{4}, 30 \mathrm{~mL} / \mathrm{L} \mathrm{NaH}_{2} \mathrm{PO}_{2}, 30 \mathrm{~mL} / \mathrm{L} \mathrm{H}_{3} \mathrm{BO}_{3}$ and $15 \mathrm{~mL} / \mathrm{L} \mathrm{Na}_{3} \mathrm{C}_{6} \mathrm{H}_{5} \mathrm{O}_{7}$. The solution was stirred with a magnetic stirrer, then heated to $65{ }^{\circ} \mathrm{C}$ in a water bath for $2 \mathrm{~h}$ in order to keep a homogeneous growth of copper on the surface of graphene.

Atomized pure-aluminum powder (Anshan Steel Industrial Fine Aluminum, Inc., China) with an average size of $20 \mathrm{um}$ and chemical composition of (Fe 0.071 $w / \%$, Si $0.067 w / \%, \mathrm{Cu} 0.002 w / \%$ ) was used as the matrix material.

\subsection{Composite preparation}

A planetary machine was used for ball milling without an interruption under high-purity (99.999\%) argon gas. The stainless-steel vial was sealed with an elastomeric $\mathrm{O}$ ring. The stainless-steel balls to powder weight ratio was $7: 1$, and the rotation rate of the vial was $40 \mathrm{~min}^{-1}$ under the total milling time of $72 \mathrm{~h}$.

A variety of ball-milled powders were fabricated by varying the mass fraction of graphene sheets (i.e., 0.25, 0.5 , and $1.0 \mathrm{w} / \%$ ). The ball-milled powder was containerized in a heat-resisting steel die $(50 \mathrm{~mm}$ in diameter, $200 \mathrm{~mm}$ in height, and $10 \mathrm{~mm}$ in thickness) and was compacted. The compacted composite billets were sintered at $610{ }^{\circ} \mathrm{C}$ for $1.5 \mathrm{~h}$ under a pressure of $25 \mathrm{MPa}$ with hot-press sintering. For comparison, a pure $\mathrm{Al}$ sample was also fabricated under the same conditions.

\subsection{Characterization}

An X-ray diffraction analysis of polished sintered sample bars was carried out with an X-ray diffractometer (Rigaku Ultima IV), using $\mathrm{Cu} K_{\alpha}$ radiation for 20-90 degrees. Raw XRD data were refined and analyzed via the MDI Jade 6.0 program (Materials Data Incorporated: Livermore, CA, USA). The surface morphology was observed with a scanning electron microscope (SEM) S-3400N equipped with an energy-dispersive spectrometer (EDS).

The tensile properties of the sintered samples with the standard specimen sizes of $(20 \times 4 \times 2) \mathrm{mm}$ were determined with a testing machine (UTM4304, Shenzhen Suns Technology Stock Co., Ltd, China) at ambient temperature using a displacement rate of $0.5 \mathrm{~mm} / \mathrm{min}$.

\section{RESULTS AND DISCUSSION}

\subsection{Microstructure}

Figure 1 shows the representative morphology of graphene and graphene-coated $\mathrm{Cu}$. Graphene has a twodimensional high-aspect-ratio sheet geometry, and the wrinkles and folds are also shown on the exfoliated graphene sheet, as depicted in Figure 1a. The graphene consists of platelets with a morphology of irregularly shaped flakes, whose mean diameters are in a range of 0.5-15 um. Agglomerated powders have an opaque structure. The thickness of the graphene sheets is several nanometers (3-20 nm), corresponding to approximately 10-50 sheets of graphene (assuming that the thickness of monolayer graphene is $0.35 \mathrm{~nm}^{26}$ ). In Figure $\mathbf{1 b}$, the graphene is covered with fine crystal particles. These particles are distributed uniformly on the surface of the graphene slice. It is concluded that these particles contain a large amount of copper particles. 


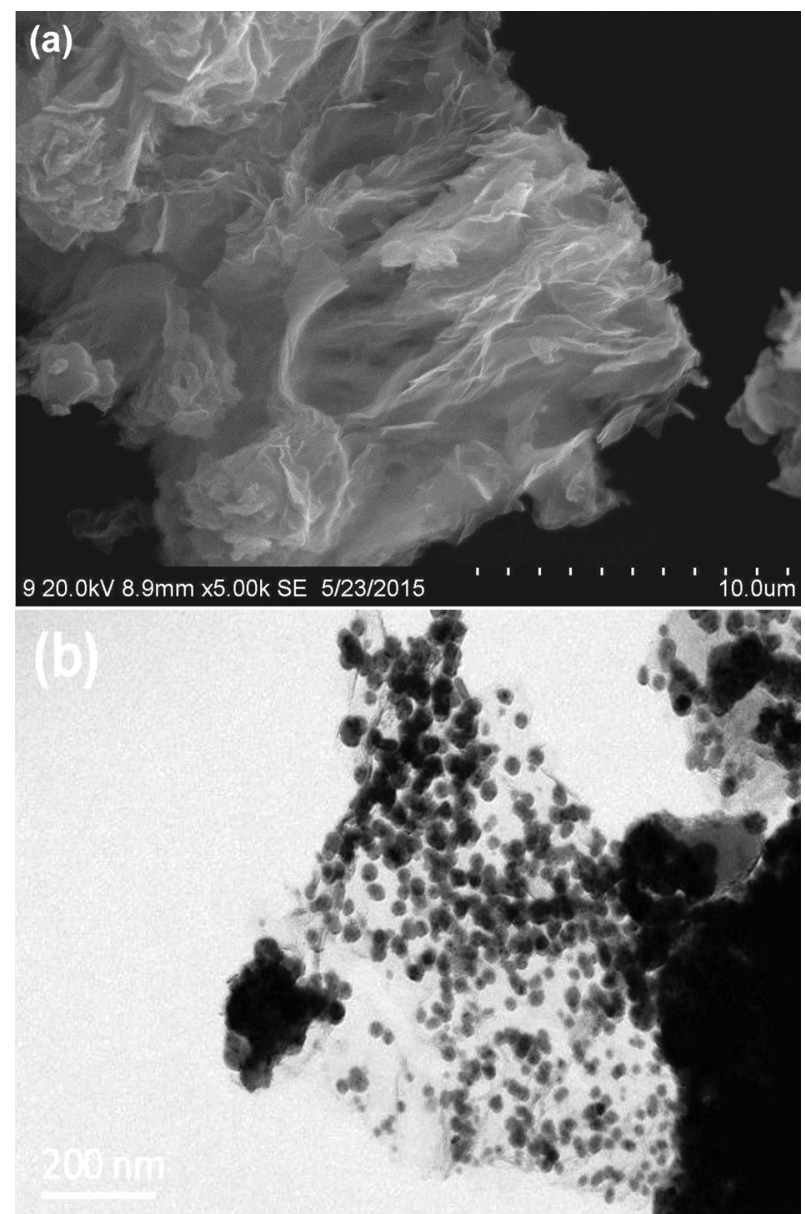

Figure 1: SEM and TEM images depicting the morphology of graphene, a) SEM morphology of graphene, b) TEM image of the copper-coated graphene

Figure 2 shows the distribution of graphene on the aluminum surfaces of the samples with different graphene contents. As shown in Figure 2, there are many fine platelets on the surfaces of the graphene/Al compo-

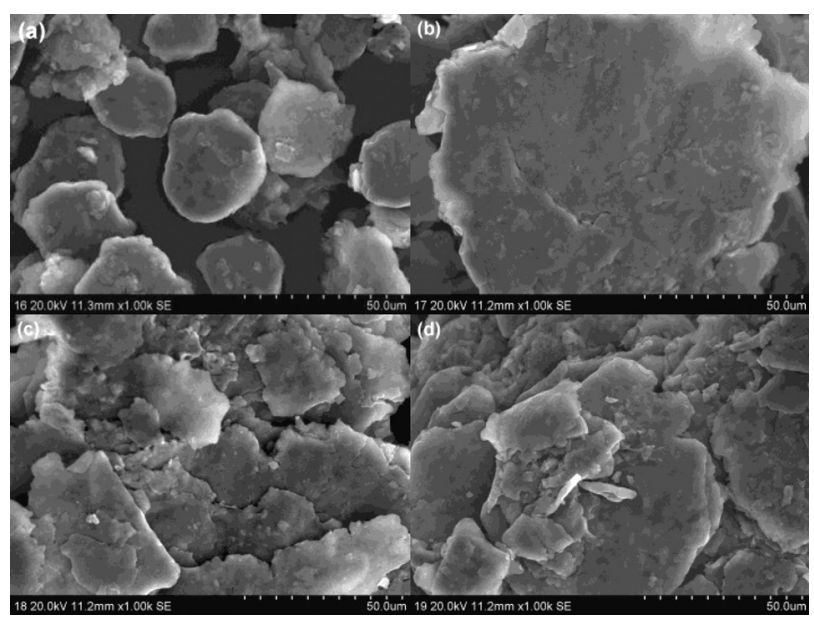

Figure 2: SEM micrographs of the mixture of aluminum powder particles and different graphene amounts after $72 \mathrm{~h}$, a) pure Al, b) 0.25 $w / \%$, c) $0.5 w / \%$, d) $1.0 w / \%$ site powders (Figures $\mathbf{2 b}$ to $\mathbf{2} \mathbf{d}$ ), while the surface of the pure Al flakes is very clear. As the graphene contents increase, the fine platelets show a dense distribution. It is indicated that the fine platelets are signs of a homogeneous dispersion of the graphene nanosheets. It is believed that, in this study, the shape compatibility of the $\mathrm{Al}$ flakes and graphene nanosheets is crucial to achieve a uniform dispersion.

Figure 3 shows X-ray diffraction patterns from pure $\mathrm{Al}$ and its composites in the sintered condition. As shown in Figure 3, a small amount of magnesium $(2 \theta=$ $35.2^{\circ}$ ) is included in pure Al. No diffraction peaks of the carbon element are present in the graphene/Al composites. This is attributed to the nanometric size and the low content of the reinforcement phase, which cannot be detected due to the detection limit presented by XRD for the second phases. ${ }^{27}$ However, no aluminium carbide $\left(\mathrm{Al}_{4} \mathrm{C}_{3}\right)$ peak is recorded for any of the samples. It is believed that there is no chemical reaction between graphene and the $\mathrm{Al}$ matrix under this condition. Bartolucci et al. reported a formation of aluminum carbide in graphene/aluminum composites processed with hot extrusion. ${ }^{17}$ Bustamante et al. thought that the formation of aluminum carbide is strongly dependent on the processing temperature of the production of the composites. ${ }^{28}$ Our results calculated in the previous work showed that the interaction between $\mathrm{C}$ and $\mathrm{Al}$ atoms is in the Van Der Waals range, indicating that there is no chemical bonding between graphene and $\mathrm{Al}^{29}$ As also shown in Figure 3, an amount of the $\mathrm{Al}_{2} \mathrm{CuMg}(\mathrm{S})$ phase is also detected in the graphene/Al composites, which is the main strengthening phase of $\mathrm{Al}-\mathrm{Cu}-\mathrm{Mg}$ alloys. However, in the current study, $\mathrm{Al}_{2} \mathrm{CuMg}$ phases are generated from the copper-coated graphene and Al matrix during the sintering process.

\subsection{Mechanical properties}

The tensile properties of the graphene/Al composites with different graphene contents are shown in Figure 4.

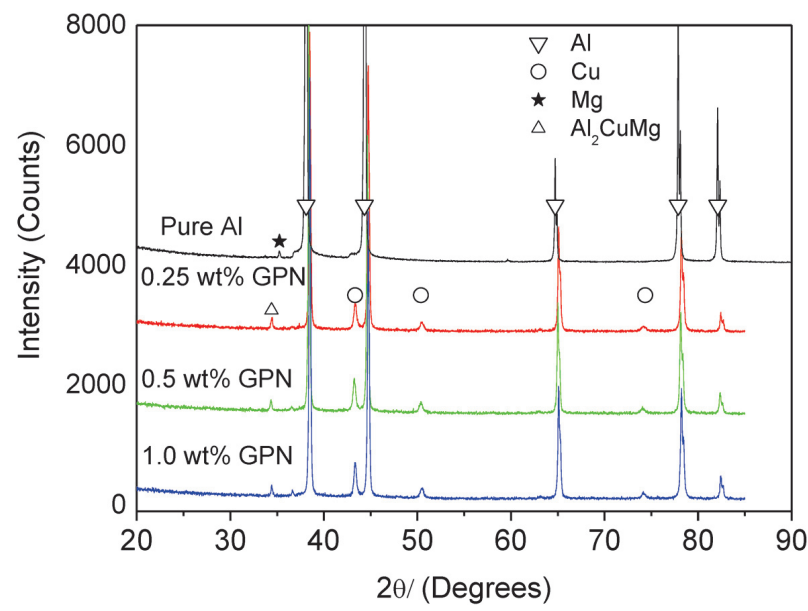

Figure 3: XRD patterns of pure $\mathrm{Al}$ and various graphene/Al composites 
Figure 4a shows the representative engineering stressstrain curves of the graphene/Al composites with different graphene contents. Figure $\mathbf{4 b}$ shows the relationship of the ultimate tensile strength (UTS) and elongation to fracture $(\delta)$ of the graphene/Al composites. The strengthening effects are first enhanced and then they deteriorate with the increasing graphene contents. When the graphene content is $0.5 w / \%$, the UTS and $\delta$ of the composites reach the maximum value. As shown in Figure $4 \mathbf{b}$, the composites with additions of 0.25 or 0.5 w/\% graphene exhibit UTS values of 174.4 and 178.3 $\mathrm{MPa}$, which indicate $28.1-\%$ and $31-\%$ enhancements over the aluminum-matrix sample $(136.1 \mathrm{MPa})$. The same strong improvement of the tensile strength is seen in the aluminum-graphene composite. ${ }^{24}$ Generally, the strengthening mechanisms include: a) Orowan strengthening, b) grain refinement, c) dislocation generation due to a different coefficient of thermal expansion (CTE) of reinforcements and matrix, and d) load transfer of graphene. ${ }^{30}$ In the present work, the contribution of Orowan strengthening can be ignored considering the size and volume fraction of the graphene. ${ }^{31}$

The strengthening mechanism can be explained as follows: Firstly, the graphene with a super-high strength,
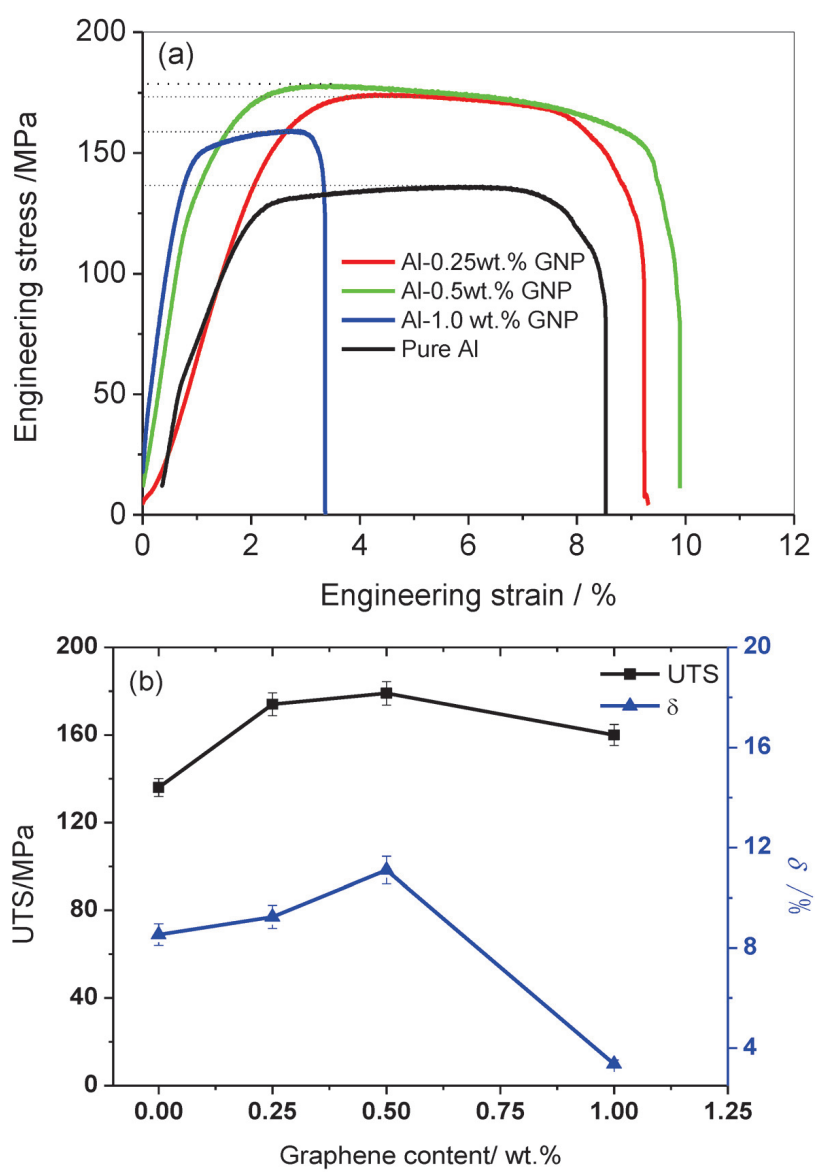

Figure 4: Tensile properties of graphene/Al composites with different graphene contents, a) stress-strain curves, b) relationship of UTS and $\delta$ with the graphene content a nanometric size and a homogeneous dispersion in the aluminum matrix (Figures $\mathbf{2 a}$ and $\mathbf{2 b}$ ) acts as the reinforcement contributing to the mechanical strengthening of bulk nanostructured graphene/Al composites. Second$1 y$, the $\mathrm{Cu}$ on the graphene surfaces improves the interfacial bonding between the aluminum matrix and graphene (Figures 2d and 3), effectively loading the transfer from the aluminum matrix to graphene, reported as the strongest material ever measured (ultimate strength of $130 \mathrm{GPa})^{14}$. Thirdly, graphene is uniformly dispersed at the grain boundaries of the aluminum matrix, as shown in Figures $\mathbf{2 a}$ and $\mathbf{2 b}$, thus hampering the migration of the grain boundaries and effectively hindering the grain growth during the hot-press sintering at elevated temperatures. Finally, the thermal-expansion-coefficient mismatch between aluminum and graphene $\left(-0.8 \times 10^{-6} / \mathrm{K}\right.$ for graphene ${ }^{32}$ and $23.6 \times 10^{-6} / \mathrm{K}$ for $\mathrm{Al}^{30}$ ) may result in a multidirectional thermal stress at the graphene-Al interface and an improvement in the dislocation densities, which will increase the strength of the composites.

Meanwhile, a significant ductility is accompanied by elongation of the samples with the additions of $0.25 \mathrm{w} / \%$ and $0.5 w / \%$ graphene, which increases with a greater addition of graphene and reaches the values of $9.2 \%$ and $11.1 \%$ for the $0.25 w / \%$ and $0.5 w / \%$ graphene contents, compared with $8.5 \%$ for pure aluminum. This means that the strength and the ductility of the graphene/Al composites simultaneously increase. A possible reason for such unique mechanical properties of graphene/Al composites is the strong interface interaction between the graphene and aluminum matrix, leading to an effective transfer of the load from aluminum to graphene.

In contrast, the effect of a larger content $(1.0 \mathrm{w} / \%)$ of graphene on the tensile properties is adverse. Both the tensile strength and the elongation decrease with an increase in the graphene additions. In particular, the elongation of the graphene/Al composite dropped sharply from $8.5 \%$ of pure aluminum to $3.2 \%$ of the graphene/Al composite with a $1.0 \mathrm{w} / \%$ graphene content. This is attributed to the fact that it would be more and more difficult for nanostructured graphene with a large aspect ratio and great specific surface area to be dispersed homogeneously into the aluminum matrix. Thus, a poor dispersion of graphene $(>1.0 \mathrm{w} / \%)$ resulted in increased amounts of agglomeration and clusters of graphene, which in turn degraded both the strength and ductility of the graphene/Al composite. ${ }^{20}$

The tensile-fracture behavior of pure $\mathrm{Al}$ and graphene/Al composites with various contents of graphene is presented in Figure 5. It can be seen that dimples and tear ridges are tiny and uniform with distinguishing features of an obvious trend along the loading direction of the tensile stress, indicating a ductile fracture of pure Al. Compared with the pure Al (Figure 5a), the fracture surfaces of the graphene/Al composites are flat. The number of the dimples and tear ridges decreases. A few 


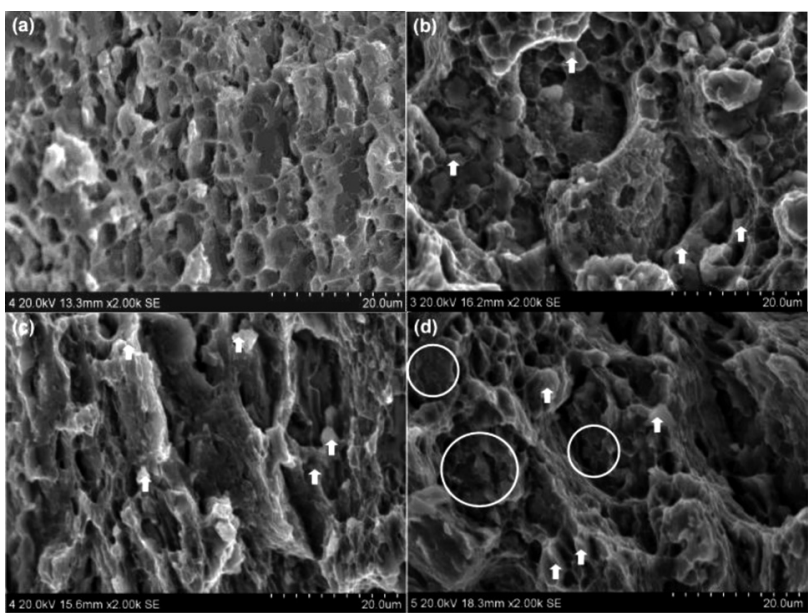

Figure 5: Tensile-fracture images of a) pure $\mathrm{Al}, \mathrm{b}) 0.25 w / \%$, c) 0.5 $w / \%$, d) $1.0 \mathrm{w} / \%$ composites

graphene sheets are observed on the fracture surface. For the $0.25 w / \%$ and $0.5 w / \%$ graphene/Al composites (shown in Figures 5b and $\mathbf{5 c}$ ), the fracture surfaces show graininess-distribution characteristics, indicating a brittle fracture. This is because graphene is mainly distributed around the grain boundaries in composite materials. When subjected to an external stress, the cracks will preferentially nucleate at the grain boundaries and expand continuously, which will eventually lead to a fracture of the composite. However, a plastic deformation of composite materials during a tension process is depressed by graphene. With an increase in the external force, the stress concentration occurs in the aluminum matrix sandwiched in graphene, in which holes appear and gradually grow up. These would cause a formation and continuous expansion of the cracks, indicating an obviously ductile fracture. Thus, there is a combination of fracture mechanisms, including ductile fracture and brittle fracture, affecting the graphene/Al composites with a lower graphene content.

With the increasing graphene contents up to $1.0 \mathrm{w} / \%$, it is found that some graphene sheets are pulled out at the edges of the tear ridges, and the graphene/Al composite exhibits many flat fracture surfaces of brittle fracture, characterized by flat dimples of different sizes or almost no dimples. Many graphene sheets are observed on the fracture surface (Figure 5d). The aggregation of the graphene is apparent as it is seriously separated from the matrix, so the cracks preferentially form in the graphene and extend to the aluminum matrix during the tensile process, decreasing the tensile strength and elongation of the graphene/Al composite. The fracture mechanism of the graphene/Al composite changes from ductile fracture to brittle fracture with the increasing graphene content.

\section{CONCLUSIONS}

Graphene-reinforced aluminum-matrix composites were successfully fabricated with ball milling and hotpress sintering. Ball milling can cause a uniform dispersion of graphene into the aluminum matrix. A modification of the graphene surface with a copper coating can improve the interfacial bonding between the graphene and aluminum matrix. When the graphene content was small, the interfacial bonding between the graphene and aluminum matrix was good. Both the UTS and $\delta$ of the graphene/Al composites increased with the increasing graphene content. The composite with a 0.5 $w / \%$ graphene content exhibited a tensile strength and elongation improvement of $31.0 \%$ and $30.6 \%$, respectively, over the unreinforced aluminum matrix. This improvement of the strength and ductility can be attributed to the homogeneous distribution of graphene in the aluminum matrix. However, as the content of graphene increased (especially up to $1.0 \mathrm{w} / \%$ ), the extent of the agglomeration of graphene within the aluminum matrix increased, lowering both the UTS and $\delta$ of the graphene/Al composites. The fracture mechanism changed from ductile to brittle with the increasing graphene content.

\section{Acknowledgment}

This work was supported by the Natural Science Foundation of Liaoning (2015602642) and Shenyang Science and Technology Project (no. 18-013-0-33) in Liaoning Province, China.

\section{REFERENCES}

${ }^{1}$ C. R. Dandekar, Y. C. Shin, Modeling of machining of composite materials: A review, Int. J. Mach. Tool. Manu., 57 (2012) 2, 102-121, doi:10.1016/j.ijmachtools.2012.01.006

${ }^{2}$ Y. Li, Y. H. Zhao, V. Ortalan, W. Liu, Z. H. Zhang, R. G. Vogt, N. D. Browning, E. J. Lavernia, J. M. Schoen, Investigation of aluminum-based nanocomposites with ultra-high strength, Mater. Sci. Eng. A, 527 (2009) 1-2, 305-316, doi:10.1016/j.msea.2009.07.067

${ }^{3}$ Y. Sumankant, C. S. Jawalkar, A. S. Verma, N. M. Suri, Fabrication of aluminium metal matrix composites with particulate reinforcement: A review, Materials Today: Proceedings, 4 (2017), 2927-2936, doi:10.1016/j.matpr.2017.02.174

${ }^{4}$ P. S. Bains, S. S. Sidhu, H. S. Payal, Fabrication and machining of metal matrix composites: A review, Mater. Manuf. Process., 31 (2016) 5, 553-573, doi:10.1080/10426914.2015.1025976

${ }^{5}$ J. Singh, A. Chauhan, Characterization of hybrid aluminum matrixcomposites for advanced applications - A review, J. Mater. Res. Technol., 5 (2016) 2, 159-169, doi:10.1016/j.jmrt.2015.05.004

${ }^{6}$ A. Mortensen, J. Llorca, Metal matrix composites, Annu. Rev. Mater. Res., 40 (2010), 243-270, doi:10.1146/annurev-matsci-070909104511

${ }^{7}$ B. S. Yigezu, P. K. Jha, M. M. Mahapatra, The key attributes of synthesizing ceramic particulate reinforced Al-based matrix composites through stir casting process: A review, Mater. Manuf. Process., 28 (2013) 9, 969-979, doi:10.1080/10426914.2012.677909 
${ }^{8}$ H. Porwal, S. Grasso, M. J. Reece, Review of graphene-ceramic matrix composites, Adv. Appl. Ceram., 112 (2013) 8, 443-454, doi:10.1179/174367613X13764308970581

${ }^{9} \mathrm{~S}$. C. Tjong, Recent progress in the development and properties of novel metal matrix nanocomposites reinforced with carbon nanotubes and graphene nanosheets, Mater. Sci. Eng. R, 74 (2013) 10, 281-350, doi:10.1016/j.mser.2013.08.001

${ }^{10}$ Z. Hu, G. Tong, D. Lin, C. Chen, H. Guo, J. Xu, L. Zhou, Graphene-reinforced metal matrix nanocomposites - a review, Mate. Sci. Technol., 32 (2016) 9, 930-953, doi:10.1080/02670836.2015. 1104018

${ }^{11}$ A. D. Moghadam, E. Omrani, P. L. Menezes, P. K. Rohatgi, Mechanical and tribological properties of self-lubricating metal matrix nanocomposites reinforced by carbon nanotubes (CNTs) and graphene - A review, Composites Part B, 77 (2015), 402-420, doi:10.1016/j.compositesb.2015.03.014

${ }^{12}$ K. S. Novoselov, A. K. Geim, S. V. Morozov, D. Jiang, Y. Zhang, S. V. Dubonos, I. V. Grigorieva, A. A. Firsov, Electric field effect in atomically thin carbon films, Science, 306 (2004) 5696, 666-669, doi: $10.1126 /$ science. 1102896

${ }^{13}$ A. A. Balandin, S. Ghosh, W. Bao, I. Calizo, D. Teweldebrhan, F. Miao, C. N. Lau, Superior thermal conductivity of singlelayer graphene, Nano Lett., 8 (2008) 3, 902-907, doi:10.1021/n10731872

${ }^{14}$ C. Lee, X. Wei, J. W. Kysar, J. Hone, Measurement of the elastic properties and intrinsic strength of monolayer graphene, Science, 321 (2008) 5887, 385-388, doi:10.1126/science.1157996

${ }^{15}$ C. Lee, X. Wei, Q. Li, R. Carpick, J. W. Kysar, J. Hone, Elastic and frictional properties of graphene, Phys. Status Solidi (B), 246 (2009) 11-12, 2562-2567, doi:10.1002/pssb.200982329

${ }^{16}$ M. A. Rafiee, J. Rafiee, Z. Wang, H. Song, Z.-Z. Yu, N. Koratkar, Enhanced mechanical properties of nanocomposites at low graphene content, ACS Nano, 3 (2009) 12, 3884-3890, doi:10.1021/ nn9010472

${ }^{17}$ S. F. Bartolucci, J. Paras, M. A. Rafiee, J. Rafiee, S. Lee, D. Kapoor, Graphene-aluminum nanocomposites, Materials Science and Engineering: A, 528 (2011) 27, 7933-7937, doi:10.1016/j.msea. 2011.07.043

${ }^{18}$ S. J. Yan, Y. Cheng, H. Q. Hu, C. J. Zhou, L. D. Bo, D. S. Long, Research of Graphene-Reinforced Aluminum Matrix Nanocomposites, J. Mater. Eng., 1 (2014) 4, 1-6, doi:10.3969/j.issn.10014381.2013.06.001

${ }^{19}$ A. F. Boostani, S. Tahamtan, Z. Jiang, D. Wei, S. Yazdani, R. A. Khosroshahi, Enhanced tensile properties of aluminium matrix composites reinforced with graphene encapsulated $\mathrm{SiC}$ nanoparticles, Composites Part A: Applied Science and Manufacturing, 68 (2015) 2, 155-163, doi:10.1016/j.compositesa.2014.10.010

${ }^{20}$ J. L. Li, Y. C. Xiong, X. D. Wang, S. J. Yan, C. Yang, W. W. He, J. Z. Chen, S. Q. Wang, X. Y. Zhang, S. L. Dai, Microstructure and tensile properties of bulk nanostructured aluminum/graphene composites prepared via cryomilling, Materials Science and Engineering: A, 626 (2015), 400-405, doi:10.1016/j.msea.2014.12.102

${ }^{21}$ M. Rashad, F. Pan, A. Tang, M. Asif, Effect of graphene nanoplatelets addition on mechanical properties of pure aluminum using a semi-powder method, Progress in Natural Science: Materials International, 24 (2014) 2, 101-108, doi:10.1016/j.pnsc.2014.03.012

${ }^{22}$ S. E. Shin, H. J. Choi, J. H. Shin, D. H. Bae, Strengthening behavior of few-layered graphene/aluminum composites, Carbon, 82 (2015) 63, 143-151, doi:10.1016/j.carbon.2014.10.044

${ }^{23}$ Z. Li, G. Fan, Z. Tan, Q. Guo, D. Xiong, Y. Su, Z. Q. Li, D. Zhang, Uniform dispersion of graphene oxide in aluminum powder by direct electrostatic adsorption for fabrication of graphene/aluminum composites, Nanotechnology, 25 (2014) 32, 325601, doi:10.1088/ 0957-4484/25/32/325601

${ }^{24}$ J. Wang, Z. Li, G. Fan, H. Pan, Z. Chen, D. Zhang, Reinforcement with graphene nanosheets in aluminum matrix composites, Scripta Materialia, 66 (2012) 8, 594-597, doi:10.1016/j.scriptamat. 2012.01.012

${ }^{25}$ W. S. Hummers, R. Offeman, Preparation of graphitic oxide, J. Am. Chem. Soc., 80 (1958) 6, 1339

${ }^{26}$ W. Choi, I. Lahiri, R. Seelaboyina, Y. S. Kang, Synthesis of graphene and its applications: a review, Crit. Rev. Solid State Mater. Sci., 35 (2010) 1, 52-71, doi:10.1080/10408430903505036

${ }^{27}$ C. Suryanarayana, E. Ivanov, V. V. Boldyrev, The science and technology of mechanical alloying, Mater. Sci. Eng. A, 304-306 (2001) 1, 151-158, doi:10.1016/S0921-5093(00)01465-9

${ }^{28}$ R. P. Bustamante, F. P. Bustamante, I. E. Guel, L. L. Jiménez, M. M. Yoshida, R. M. Sánchez, Effect of milling time and CNT concentration on hardness of CNT/A12024 composites produced by mechanical alloying, Mater. Charact., 75 (2013) 1, 13-19, doi:10.1016/j.matchar.2012.09.005

${ }^{29}$ X. M. Du, K. F. Zheng, R. Q. Cheng, F. G. Liu, First-principle study of the interaction between graphene and metals, Dig. J. Nanomater. Bios., 12 (2017) 2, 463-471

${ }^{30}$ M. Rashad, F. Pan, A. Tang, M. Asif, Effect of graphene nanoplatelets addition on mechanical properties of pure aluminum using a semi-powder method, Prog. Nat. Sci. Mater. Int., 24 (2014) 2, 101-108, doi:10.1016/j.pnsc.2014.03.012

${ }^{31}$ Z. Zhang, D. Chen, Consideration of Orowan strengthening effect in particulate-reinforced metal matrix nanocomposites: a model for predicting their yield strength, Scr. Mater., 54 (2006) 7, 1321-1326, doi:10.1016/j.scriptamat.2005.12.017

${ }^{32}$ D. Yoon, Y. W. Son, H. Cheong, Negative thermal expansion coefficient of graphene measured by Raman spectroscopy, Nano Lett., 11 (2011) 8, 3227-3231, doi:10.1021/nl201488g 